\title{
An Investigation the Gender Difference into the Status of Intrinsic Motivation towards Science Learning Among Intermediate Science Students
}

\author{
Sarwat Mubeen, Dr.Safia Saeed ,Dr.Col(R).M. H. Arif \\ University of Wah, Wah Cantt. Foundation University, Islamabad
}

\begin{abstract}
Motivation is the internal state that arouses, directs, and sustains goal-oriented behavior. In particular, motivation to learn refers to the disposition of students to find academic activities relevant and worthwhile who try to derive the intended benefits from them. In studying the motivation to learn science, researchers examine why students strive to learn science, how intensively they strive, and what beliefs, feelings, and emotions characterize them in this process. Motivated learners are thus self regulated learners who attempt to monitor and control their own learning. Intrinsic motivation and personal relevance is major motivational component that appear to influence self-regulated learning. The purpose of the study is to investigate the gender differences into the status of intrinsic motivation and personal relevance towards science learning among intermediate science students. A sample of 600 intermediate science students from Punjab (Pakistan), in which 300 males and 300 females were serve as the sample of the study which were selected through two phase cluster sampling. The 30-item Science Motivation Questionnaire developed by Glynn and Koballa (2006) was used to measure intrinsic motivation and personal relevance scores towards science. The scores were calculated and summarized through mean and standard deviation. The significance of difference between mean scores of male and female intermediate students was measured by t-test (two-tailed). The result revealed that male and female science students did not differ in science motivation, however female science students were found some what better in their motivation towards science than males.
\end{abstract}

Key Words: Gender difference, intrinsic motivation, science learning

\section{Introduction}

Motivation is a significantly important factor for academic learning and achievement across childhood through adolescence (Elliot and Deweck, 2005). It is generally agreed that motivation has positive impact upon learning; it stimulates, sustains and give directions to an activity. Highly motivated students often require little guidance from the teachers and are capable of doing many higher degree of complicated work independently. Usually environmental condition can motivate students other mother motivational factors include parental pressure, classroom environment, teacher and peer approval may contribute to the motivation of the child. (Siddiqui, 2004).

The $21^{\text {st }}$ century is characterized by advancement in science and technology (Okebukola, 1996). In this, every nation is striving to achieve scientific and technological break through with their environment. Thus, the teaching of science and technology is becoming more demand and activity oriented than before. The youths are taught science in relation to their environment for the improvement of their conditions of living and for economic growth. Achievement of the development and growth through science and technology requires qualitative science and technology. It is clear evidence that achieving quality science and technology education depends largely on the effectiveness on science students. (Ezeliora, 2005).

Students' conceptualizations are important in their own right, however, particularly within a socialconstructivist view of learning science, because students' conceptualizations influence their action (McGinnis et al., 2002; Scott, Asoko and Leach, 2007).

This study "Investigation the gender difference into the status of intrinsic motivation and personal relevance towards science learning among intermediate science students through science motivation questionnaire (2006) at the college level". The study was examined students' conceptualizations of their motivation to learn science. The 30-item Science Motivation Questionnaire developed by Glynn and Koballa (2006) was used as authors desired to cross validate it in other countries.

For many years, the philosophers and researchers are trying to find the most effective strategies to make learning better. For this reason, different learning and teaching strategies have been developed. After the middle of 18th century, Blooms taxonomy becomes the key classification of educational objectives for better learning with its three domains; cognitive, affective and psychomotor. This classification makes the educational researchers realize that it is not enough to decide the best teaching method or the most effective teaching 
strategy alone; instead, students' feelings, interests, attributions, ideas, emotions, goals are also very important for giving meaning to what is being taught to them(Gardner 1999; Goleman 1996; Morgan 2006). This was the time, "affective domain" found its place in educational area. After realizing the significance of affective domain, educational researches made effort accordingly, concluding that better learning occurs when students are activated by their affective domains, next to cognitive domain. This recognition opened a new research area which aimed to define the components of affective domain. For example, Brown (1994) defined affective domain as "the emotional side of human behavior." (p. 135) that simply includes all of the emotions that a human being shows which can easily be put under this domain. According to Baloom, Krathwhol and Masia (1964) the affective domain includes attitudes, emotions, and also five sub-categories in this domain that are the receiving responding, valuing; organizing values and internalizing values.

Under the light of many researchers' findings, there are some variables that under affective domain proved to be very effective in students' learning. These are motivation, attitudes, self efficacy and anxiety (Akbas and Kan, 2006). All these constructs have their unique importance in students' learning. But one of them occupies more space in educational research, motivation of the students. Being the centre of educators, motivation has been defined from many different angles which result it to have many components and constructs. According to Brown (1994), motivation is an inner drive, impulse, emotion, or desire that moves a person. According to Pintrich and schunk (2002), motivation is "a process for goal-directed activity that is instigated and sustained" (p.5).

Despite the fact that motivation is a key component to instruction and learning, one standard definition for the hypothetical construct of motivation does not seem to exist. Initially, the study of motivation was linked to primitive drives and needs (Weiner, 1990). This is an antique view of motivation. Moshinskie (2001) uses the definition, "The attention and effort required to complete a learning task and then apply the new material to the worksite". Moshinskie's definition is not detailed. Between these two ideas exists a body of research related to motivation. Bandura (1997) identifies three different forms of motivation around which different theories have been built. Those theories are attribution theory, expectancy-value theory, and goal theory. According to Reeve, Hmm and Nix (2003), when students believe they have some degree of control over their learning, their motivation is increased.

These definitions of the researchers show that the intrinsic and extrinsic motivation and personal relevance is important motivational construct.

Motivations can be categorized into two groups, intrinsic and extrinsic. These terms both seek to identify the placement or location of ones' desire to perform a particular task or exhibit a certain behavior. When this desire is formed around the attainment of external rewards, it is referred to as extrinsic motivation. Conversely, intrinsic motivation is experienced when one denies the external reinforcements and acts to enjoy the task at hand (Aronson, W et al, 2002).

Ladislav Duric (1990), internal motivation is considered to be a state 'forcing' the individual to do something or to learn something for personal satisfaction, to broaden personal experience. The human being internally motivated to learn does so willingly, since the learning itself provides pleasure and satisfaction.

Conti (2001), found that intrinsically motivated people are less concerned with the difficulties of a certain task and how long it takes, than someone who is more extrinsically motivated. Similarly, when people are intrinsically motivated to engage in certain tasks, they experience many positive traits such as a rise in creativity levels, the ability to perform better, the preference of a challenging task and remaining interested for a longer period of time. The rewards gained for completing an interesting task impair a person's intrinsic motivation for the given activity. The person participating will enjoy the task less and be more likely to disengage himself (Cameron, 2001).

The drop of motivation or interest in tasks at hand is most likely to be related to a reward factor. Research shows that when people receive rewards for completing tasks, they will enjoy it less and spend less time to complete that task (Pierce, Cameron and Banko, 2003). Therefore, if students participate in research studies for the sole reason of receiving credit, their extrinsic motivation might cause loss of interest in the tests or questionnaires in front of them and as a result, they might speed through providing mediocre, and possibly, inaccurate data. According to Cavallo, Rozman, Blinkenstaff and Walker (2003), goal orientation can be linked to intrinsic and extrinsic motivation since students with learning goals tend to be extrinsically motivated, trying to get the highest grades and impress their instructors.

Whether or not motivation influences performance depends on (a) whether the person finds a suitable context or opportunity for the expression of that motivation, (b) the extent to which the environment provides suitable contexts, and (c) the extent to which the environment recognizes and rewards the visible products of that motivation. Thus, the path from motivation to performance is not a linear one, and obstacles can prevent highly motivated persons to perform accordingly.

For example, students high in intrinsic motivation may fail performing at high levels if they are given tasks that do not allow creativity or if their creative task-solutions are not appropriately recognized and 
rewarded. By the same token, students high in extrinsic motivation may fail performing at high levels if they are not given sufficient incentives or if they are required to produce creative task-solutions and creativity is validly assessed. Thus, the effects that trait and state motivation, intrinsic and extrinsic motivations have on academic performance can be greatly modified by the characteristic of the environment within which students operate. (Amabile, 1994).

The potential value of the Science Motivation Questionnaire is that it can provide information about how motivated a student is and why a student is motivated or not motivated to learn science. This information can be useful to science instructors and science education researchers in fostering motivation, and thereby, achievement. The researcher examined student's conceptualizations' of their motivation to learn science.

\subsection{Objective Of The Study}

The main objective of the study was:

- To investigate the gender differences into the status of intrinsic motivation and personal relevance towards science learning among intermediate science students.

\subsection{Research Question}

A research question was:

- $\quad$ Are there gender differences in students' motivation to learn science?

\subsection{Hypotheses}

Keeping in view the research objective and thorough review of research literature on intrinsic motivation and personal relevance to learn science, the following null hypothesis was developed:

- Science motivation scores towards intrinsic motivation and personal relevance of male and female intermediate science students is not same.

\subsection{Sample}

\section{Research Methodology}

A sample of 600 intermediate science students in Punjab (Pakistan) served as the sample of the study which was selected through two phase cluster sampling by using the following sampling procedure:

1. Three districts of Gujarat, Gujranwala and Rawalpindi were randomly selected through cluster sampling from 36 districts of the Punjab province.

2. 200 students, 100 boys and 100 girls, were randomly selected from the colleges located in each district headquarter.

At the first stage of sample selection, 20 colleges were randomly selected, 6 (male and female) colleges from district Gujarat, 6 (male and female) colleges from district Gujranwala and 8 (male and female) colleges from Rawalpindi. 600 students were randomly chosen from the selected colleges.

\section{2 Research Instrument}

The 30-item Science Motivation Questionnaire developed by Glynn and Koballa (2006), based on the five factors was used as author permitted it to cross validate in other countries. The items were strongly worded, unambiguous declarative statement in the form of short and simple sentences. The statements were easy to read. Students were to respond to each of the 30 randomly ordered items on a five-point Likert-type scale of ranging from 5 (strongly agree) to 1 (strongly disagree).

Data were collected from students in classroom with the permission of concerned authorities. Before administering the instrument, all students were thoroughly briefed about instrument.

\section{Results}

Researcher used Statistical Program for the Social Sciences (SPSS) version 17.0, to analyze the data. The scores were calculated and summarized through mean and standard deviation. The significance of difference between mean scores of male and female intermediate students was measured by t-test (two-tailed).

Table 1. Significance of difference between mean science motivation scores of male and female students towards intrinsic motivation and personal relevance.

\begin{tabular}{|l|l|l|l|l|l|l|}
\hline Gender & $\mathbf{N}$ & Mean & SD & SEdiff & t & p \\
\cline { 1 - 5 } Male & 300 & 38.63 & 2.85 & $.22 \quad .85$ & $>.05$ \\
\hline Female & 300 & 38.96 & 2.59 & & & \\
\hline
\end{tabular}


The above table shows that the obtained $t$ value of .85 is not significant at .05 level so the null hypothesis on this motivation factor is retained and it is concluded that there is no significant difference between mean intrinsic motivation and personal relevance scores of male and female students.

\section{Conclusion}

Male and female science students did not differ in science motivation, however female science students were found better in their motivation towards science than males.

\section{Discussion}

The results shows that there is no gender difference have been found between mean science motivation scores of male and female students towards intrinsic motivation and personal relevance, although girls are intrinsically somewhat better as compare to boys in science learning.

Previous studies support the study's result. Girls showed a greater intrinsic motivation (Mecca and Holt, 1993). According to Husman and Lens (1999), highly intrinsically motivated students can simultaneously be extrinsic in terms of future goal orientation. Young children with higher academic intrinsic motivation functioned more effectively in school (Gottfried, 1990).

Intrinsically motivated learners achieve better results in knowledge tests, have a highly positive learning self-concept. In comparison with their peers with low intrinsic motivation, they show also less academic anxiety, and are less dependent on external motivational stimuli (Gottfried, 1985). Highly intrinsically motivated students are more successful in learning new concepts and show better understanding of the learning material (Stipek, 1998). Renni (1990), on the basis of a research study on science learning, concluded that higher results in science were related to the learner's active engagement in learning tasks, to his or her positive attitude towards the subject and to a highly positive self-concept in science, which all imply the learner's intrinsic motivation to learn. The researcher of the study believe that the intrinsic motivation to learn science (task too easy, task too difficult) could in the future be maintained and supported by developing strategies which would blocked the 'demotivators'.

Nadia (2010) found gender difference on the variable of extrinsic and intrinsic motivation on academic performance ( $\mathrm{t}: 4.324, p<.05)$. Findings of the study suggested that females were more intrinsically motivated than males. In contrast, male were more extrinsically motivated than females. These findings are consistent with Chee, Pino and Smith (2005) who indicated that female college students were more likely to have higher academic ethics than male students, which are characterized by higher academic attainments.

\section{References}

[1] Akbas and A. Kan, Affective Factors that Influence Chemistry Achievement (Motivation and Anxiety) and the power of These Factors to Predict Chemistry Achievement-II, Journal of Turkish Science Education, 4(1),2006.

T.M. Amabile, The Social Psychology of Creativity, (Springer-Verlag, New-York, NY, 1992).

[3] E. Aronson, T. D. Wilson, and R.M. Akert, Social Psychology. (Upper Saddle River, New Jersey: Prentice Hall. 2002).

[4] A.Bandura, Self-Efficacy: The Exercise of Control. (New-York, Freeman. 1997).

[5] H. D. Brown, Teaching by Principles: An Interactive to language Pedagogy. (Upper Saddle River, New Jersey: Prentice Hall. 1994)

[6] J. Cameron, Negative Effects of Reward on Intrinsic Motivation-A limited phenomenon: Comment on Deci, Koestner, and Ryan. 2001. Review of Educational Research, 71(1), 2001.29-42.

[7] A.M.L.Cavallo, M. Rozman, J. Blinkenstaff, and N.Walker, Students Learning Approaches, Reasoning Abilities, Motivational Goals, and Epistemological Beliefs in Differing College Science Courses. Journal of College Science Teaching 33(3): 2003, 1823.

[8] K.H.Chee, N.W. Pino, and W.L. Smith, Gender Differences in the Academic Ethics and Academic Achievement. College Student Journal 39(3), 2005, 604-19.

[9] R.Conti, Time flies: Investigating the Connection between Intrinsic Motivation and the Experience of Time. Journal of Personality, 69, 2001. 1-26.

[10] Ezeliora, B. Teacher Factor: A Challenge to the Implementation of Primary Science Curriculum. Curriculum Issues in Contemporary Education. (Da-Sylva influence. Benin Nigeria, 2005).

[11] Gardener, R.C. Correlation, Causation, Motivation and Second Language acquisition. Address at The Canadian Psychological Association Annual Meeting, Halifax, Canadian Psychology, 40, 70. 1999.

[12] S. M. Glynn, and T.R. Koballa, Motivation to Learn College Science. In J. J.

[13] Mintzes \& W. H. Leonard (Eds.), Handbook of college science teaching, Arlington, VA: National Science Teachers Association Press. 2006, 25-32

[14] D. Goleman, Emotional Intelligence: why it can matter more than IQ. London: Bloomsbury.1996.

[15] A.Gottfried, Academic Intrinsic Motivation in Elementary and Junior High Students.

[16] Journal of Educational Psychology, 82, 1985, 525-538. Nadia, Effect of Intrinsic and Extrinsic Motivation on Academic Performance.

[17] Department of Social Sciences, College of Business Management, Karachi. 2010.

[18] A.E. Gottfried, Academic Intrinsic motivation in Elementary School Children.

[19] Journal of Educational Psychology; 82(3), 1990, 525-538.

[20] J. Husman, and W. Lens, The Role of the Future in Student Motivation.

[21] Educational Psychologists, 34(2), 1999, 113-125

[22] D. Ladislav, Essentials of Educational Psychology, Educational Science, prepared for the International Bureau of Education, 1990, pp91-92. 
[23] L. J. Mecce, and K. Holt, A pattern analysis of students' achievement goals. Journal of Educational Psychology,85,1993,582-590.

[24] J.R. McGinnis, S. Karmer G. Shama, A.O. Greaber, C.A.Parker and Watanabe, Undergraduates' and Beliefs about Subject matter and Pedagogy Measured

[25] Periodically in a Reformed Based Mathematics and Science Teacher Preparation Program. Journal of Research in Science Teaching, 39, 2002, 713-737.

[26] Morgan, Improving Your Students' Learning: Reflections on The Experience Of Study London, Kogan Page, 2006.

[27] J. Moshinskie, How to Keep e-Learning from escaping. Performance Improvement, 40(6). Retrieved on Jun 24, 2008 from http.//web.mit.edu/newsoffice/2001/elearning-0915.html.

[28] P. Okebukola, Making Science learner-friendly: A Challenge for Science Teacher. STAN Newsletter, 1996, Vol. 3(1).

[29] Pierce, W. D., Cameron, J., and Banko, K.M., Possitive Effects of Rewards and Performance Standards on Intrinsic Motivation. Psychological Records , 53, 2003, 561-579.

[30] P.R. Pintrich, and D. H. Schunk, Motivation in education: Theory, research, and Applications (2 ${ }^{\text {nd }}$ Ed.). Columbus, OH: MerrillPrentice Hall. 2002.

[31] L.J. Rennie, Student Participation and Motivational Orientation: What StudentsDo in Science? In K. Tobin, J. Butler and B. J. Fraser (Eds.), Windows into Science Classrooms: Problem Associated with Higher-Level Cognitive Learning London. The Falmer Press. 1990, pp164-198.

[32] J. Reeve, D. Hmm, G. and Nix, Testing Models of the Experience of Self- Determination in Intrinsic Motivation and the Conundrum of Choice. Journal of Educational Psychology, 95, 2003, 375-392.

[33] P. Scott, H. Asoko, and Leach, Students Conception and Conceptual Learning in Science. In S.K. Abell and N.G. Laderman (Eds)., The Hand Book of Research Science Education., Mahwah, NJ: Erlbaum. 2007, pp31-56

[34] M. H. Siddiuqi, Research in Teaching of Science and Mathematics. Ashish Publishing House , 8/81 Punjabi Bagh, New Dehli, India 2004,.pp. 9-15.

[35] D. Stipek, Motivation to Learn: From Theory to Practice. Boston: Allyn and Bacon, 1998.

[36] Weiner, History of motivational research in education. Journal of Educational Psychology, 82(4), 1990, 616-622. 